\title{
Influence of a waterfall over richness and similarity in adjoining pools of an Atlantic Rainforest stream
}

\author{
Influência de uma queda d'água sobre a riqueza e a
}

similaridade de dois remansos em um rio da Mata Atlântica

Célio Roberto Jönck ${ }^{1}$ and José Marcelo Rocha Aranha ${ }^{2}$
${ }^{1}$ Avaliação e Monitoramento Ambiental, Centro de Pesquisas Leopoldo Américo Miguez de Melo, CEP 21941-915, Rio de Janeiro, RJ, Brazil e-mail: biocelio@yahoo.com.br

${ }^{2}$ Laboratório de Ecologia de Rios, Universidade Federal do Paraná - UFPR, Campus Palotina, Rua 24 de Junho, 698, CEP 85950-000, Palotina, PR, Brazil e-mail: jmaranha@ufpr.br

\begin{abstract}
Aim: The main goal of the study was to determine the effect of the Morato Fall in the richness and composition of the aquatic animal community; Methods: We compared faunal richness and similarity in four substrate samples from two pools separated by a waterfall in the Morato River, southern Brazil; Results: The richness was not significantly different, although the upstream pool had 72 taxa and the downstream one just 65 . On the other hand, composition was poorly similar, just a $36.5 \%$ similarity between the two sites; Conclusions: That indicates a strong influence of the waterfall, mainly on organisms which spent its entire life cycle on the water, such as fish and small crustaceans. That allow aquatic insects, a group with airborne adult phase and, therefore, able to disperse up to the upstream pool, to evolve with less predatory pressure, becoming the top group in the food web of this environment.
\end{abstract}

Keywords: stream, waterfall, richness, similarity, Atlantic Forest.

Resumo: Objetivo: O objetivo principal foi determinar o efeito do Salto Morato na riqueza e na composição da comunidade aquática; Métodos: Nós comparamos a riqueza e a similaridade da fauna em amostras de quatro substratos de dois poços separados por uma cachoeira no Rio Morato, no sul do Brasil; Resultados: A riqueza não foi significativamente diferente, embora o poço acima do salto tenha apresentado 72 taxa e o poço abaixo do salto apenas 65. Por outro lado, a fauna apresentou-se pouco similar, com apenas 36,5\% de similaridade entre os poços; Conclusóes: Isso indicou uma forte influencia da presença da cachoeira, principalmente nos organismos que tem todo o ciclo de vida na água, como os peixes e pequenos crustáceos. Isso permite que os insetos aquáticos, que tem fase adulta alada e, portanto, a capacidade de se dispersar até o poço acima do salto, se desenvolvam sem a pressão de seus principais predadores e tornem-se, naquele ambiente, os organismos de topo da teia trófica.

Palavras-chave: riacho, cachoeira, riqueza, similaridade, Floresta Atlântica.

\section{Introduction}

The species richness is the greatest ecological feature of the Atlantic Rainforest. This biome, officially named Dense Ombrophilous Forest, is recognized as the most degraded environment in Brazil and figures among one of the eight hotspots of biodiversity pointed out by Myers et al. (2000) as a priority to conservancy actions.

In Parana State, the remnants of this vegetal formation are spread mainly over the Coastal Watershed, a $5.766 \mathrm{~km}^{2}$ drained area that includes the Serra do Mar mountain range, the coastal plain and Paranagua and Guaratuba bays (Bigarella et al., 1978).

Topographical features of Atlantic Rainforest's coastal streams include occasional waterfalls (a watercourse that drops vertically, flowing over the edge of a cliff or down a slope) in a predictable sequence of riffles (shallow sites with a very turbulent hydrology) and pools (deep sites with a low flow hydrology).

The pools are places of flow divergence which reduces the water speed and decreases the system's 
energy. This condition favors sediment depositions that build microhabitats for several kinds of organisms.

During the rainy season, these microhabitats are subject to abrupt and unpredictable flood events (Por, 1992) that flush away the less consolidated sediments and their resident organisms. The ecosystem is recovering as the sediment transport rebuilds the substrates and the biota recolonizes them.

Some studies on stream ecology mention barrier effects caused by waterfalls on stream communities (Gilliam et al., 1993; Mazzoni et al., 2006) as well as changes in predator-prey dynamics (Reznick and Ghalambor, 2005) and longitudinal abundance (Greathouse and Pringle, 2006). The study of Vilella et al. (2004) also mentions that waterfalls seem to act as selective screens more than as absolute barriers to some stream megafaunal species.

We hypothesize that the biota's recolonization on environments subject to seasonal disruptive events can be influenced by the presence of a geographic barrier, leading to differences in the biological community structure. We expect the same screen effect mentioned by Vilella et al. (2004), and the most affected organisms should be those which no other means of dispersal than the aquatic one. Organisms with only part of the life cycle in the water should have fewer difficulties to overcome the barrier.

Therefore, the aim of this study was to compare the community richness and composition of two pools in a rainforest costal stream considering the presence of a waterfall between them, seeking for evidences of its influence on the community structure.

\section{Material and Methods}

The study site is the Morato River, a third order stream located at Guaraqueçaba municipality, state of Paraná, in the southern region of Brazil at $25^{\circ} 09^{\prime} 54^{\prime \prime} \mathrm{S}$ and $48^{\circ} 17^{\prime} 50^{\prime \prime} \mathrm{W}$. The stream presents the typical riffle-pool feature and a $130 \mathrm{~m}$ high waterfall - called Morato Fall (Salto Morato) - in its median portion.

We found two pools with similar physical characteristics (approximately 8 long, $5 \mathrm{~m}$ wide and 3.5 deep) one above and another below the waterfall. The pools' bottoms are composed by a mosaic of sediments similarly distributed on both environments (approximately 60\% rocks, $20 \%$ gravel, $15 \%$ sand and $5 \%$ organic matter accumulations). To avoid the substrate destabilization caused by flash floods, all the sample campaigns were carried out before the first flood of September 2005.

We made five campaigns for this study and on each campaign we collected five samples of each substrate accumulation on every pool. The usual macro-invertebrate stream samplers, like kick-net, surber, hess, D-net and U-net described in Hauer and Resh (1996) and Melo (2003), were not efficient to collect them due to the sites' depth. On the other hand, the use of deep water samplers, such as the Ekman and Peterson dredges, described in Pérez (1988) and in Merrit et al. (1996), showed transporte and handling limitations. Besides, dredges have low efficiency for the sampling of rocks and organic matter substrates.

For these reasons we used $430 \times 255 \mathrm{~mm}$ reinforced plastic bags as samplers. The sampling was done dragging $10 \mathrm{~cm}$ from the surface of sand and gravel substrates and gathering rocks and leaf litter according to the size of bags. All of this was made directly from the substrates using free diving techniques.

The material of each sample was washed over a $0.05 \mathrm{~mm}$ mesh and living organisms were sorted out by using a trans-enlightened tray. Organisms were kept in alcohol at $70 \%$ concentration and taken to the laboratory in covered amber glass containers. All macro-invertebrates were identified up to family level. Whenever possible, they were identified up to genera level. The presence of fish species for this study was made by visual census. On each campaign we made two daily assessments of one hour, one in the morning and another at dusk, in each pool. We use the study of Barreto and Aranha (2005) as a guide to identify fish species of the Morato River.

As an exploratory approach to our data, we performed a correspondence analysis using the Past software (Hammer et al., 2001). To determine sample adequacy we estimate the environmental richness using the first order Jackknife estimator. Its good performance with small numbers of samples was determinant to the method's choice. This statistical method requires data on numbers of rare species present in the environment, considering a rare species which occurs in just one campaign (Heltshe and Forrester, 1983). The richness and similarity among different substrates, and between the areas as a whole, was measured through the Chi-square test and the Sorensen Similarity Index respectively.

\section{Results}

The correspondence analysis shows eigenvalue 0.25 in the first and 0.14 in the second axis, which 
accounted for more than $60 \%$ of the total variation of samples. The first axis separated the samples taken from upstream pool of those taken from downstream pool, while the second axis separated samples by substrate grain size. The community distribution was strongly influenced by these variables (Figure 1).

There are no significant differences in the number of taxa between each microhabitat or in the total number of taxa between the pools (Table 1). Comparison among substrates of each pool (Figure 2) showed predominance of aquatic insects, mainly Diptera, Ephemoptera and Trichoptera, which could be observed in all substrates in both areas.

It may also be observed that some taxa occurred exclusively in one of the pools, such as Anura (tadpoles), Collembolla, Plecoptera, and Turbelaria in the upstream pool and fish and crustaceans in

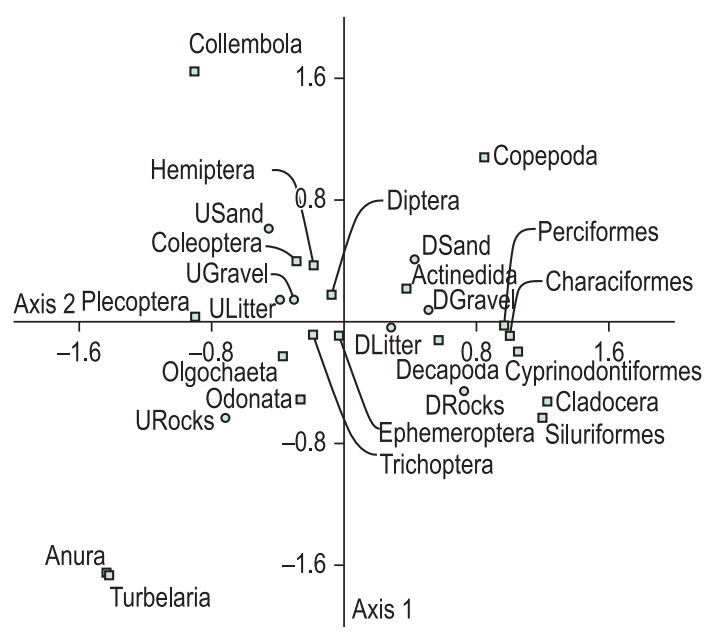

Figure 1. The correspondence analysis chart. Circle dots represent sampled substrates (D - downstream poll, and U start for upstream pool) and square dots represent taxa. the downstream one. Also related, the number of taxa of aquatic insects was always higher on the upstream pool.

The sampling adequacy was measured by the estimation of pools' richness. The upstream pool presented 28 rare species from a total richness of 72 , while downstream pool has 25 rare species from a total of 65 taxa. Estimated richness upstream was 94.4 taxa against 85.0 taxa downstream.

The similarity between both environments, measured by the Sorensen index, may be considered low, not reaching $40 \%$ in any of the substrates individually and reaching only $36.5 \%$ similarity between the pools (Table 2).

\section{Discussion}

The correspondence analysis showed, as expected, that our results were strongly influenced by spatial variation. As can be seen in Figure 1, the first axis separates study areas while the second axis indicates strong influence of particle size on the communities' distribution. Fish taxa were slightly influenced by particle size but highly influenced by the study area, while aquatic insects were almost equally influenced by both variables.

The estimation of the pools richness indicates that more than $75 \%$ of the expected taxa were present in the samples. Our results match with other medium taxonomic resolution studies, compiled by Schmid-Araya et al. (2002), which measured richness in lotic environments (from 24 to 92 taxa with an average of 46 taxa). In fact, our numbers were near the average found by high taxonomic resolution studies (84 taxa). However, the main sources of Schmid-Araya's compilation were studies performed in temperate environments. On the other hand, Motta and Uieda (2005), working on a tropical stream, found a 112 species richness that includes meiofaunal groups (Protozoans and

Table 1. Richness differences among substrates as well as whole pools. Critical $\chi^{2}$ value $=3,14 ; \mathrm{DF}=3$.

\begin{tabular}{cccccc}
\hline & Sand & Gravel & Rocks & Litter & Pool \\
\hline Montante & 24 & 41 & 36 & 38 & 72 \\
Jusante & 29 & 34 & 34 & 30 & 65 \\
$X^{2}$ & 0.47 & 0.65 & 0.06 & 0.94 & 0.35 \\
\hline
\end{tabular}

Table 2. Similarity by microhabitats and total similarity between the pools.

\begin{tabular}{ccccc}
\hline Micro-habitat & Upstream & Downstream & Match number & Sorensen Index \\
\hline Sand & 24 & 29 & 6 & 0.226 \\
Gravel & 41 & 34 & 12 & 0.320 \\
Rocks & 36 & 34 & 11 & 0.314 \\
Litter & 38 & 30 & 12 & 0.353 \\
Pools & 72 & 65 & 25 & 0.365 \\
\hline
\end{tabular}



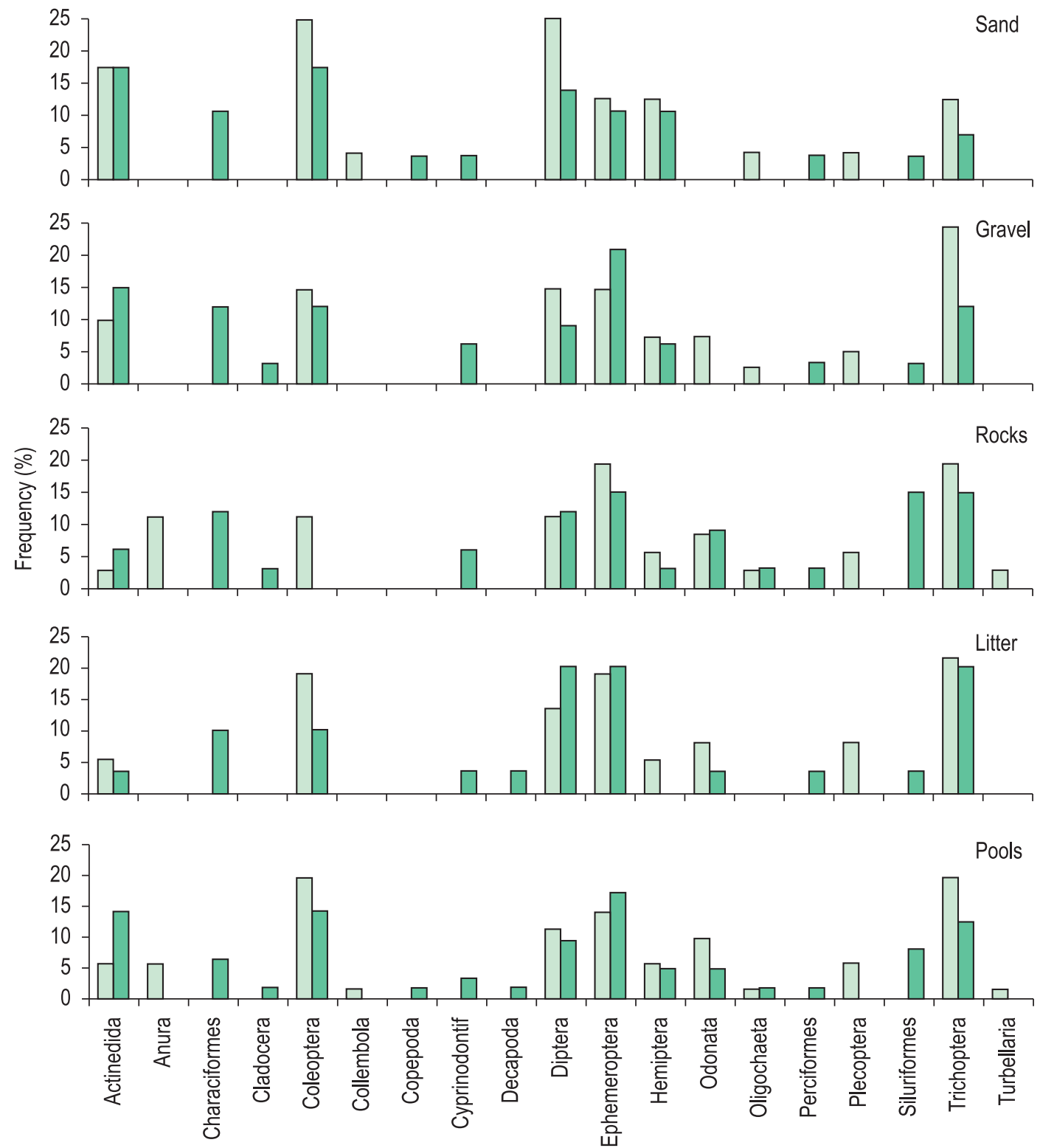

Figure 2. Taxa frequency that show composition dominance on each substrate for upstream pool (white bars) and downstream pool (black bars).

Rotifers) in high taxonomic resolution. Taking into account that our study had medium taxonomic resolution and the sampling design was not sufficiently robust to collect meiofaunal groups, we consider our results representative of the pools' communities.

The species richness found in the pools did not show significant differences, as evidenced by the Chi-square test. Other studies carried out on Atlantic Rainforest lotic ecosystems (Melo and Froehlich, 2001; Roque et al., 2003; Costa and Melo, 2008) found higher variation of richness than those found in this study, but still without significant differences.
Considering that study sites were similar in dimension, microhabitat composition, riparian coverage and river section, being approximately two kilometers apart from each other, we consider that the waterfall does not affect richness, as was predicted by the River Continuum Concept (Vannote et al., 1980).

On the other hand, the similarity between pools was very low, reaching just $36.5 \%$ by the Sorensen similarity index. This is not confirmed by related studies such as Costa and Melo (2008), which covered Atlantic Rainforest streams, and found similarity values near $60 \%$, the stream size being the only notably different variable however. Baldan (2006) found higher similarity values 
(near 50\%) working on different sections of rivers notably influenced by anthropomorphic impacts. Even Pavanelli and Caramaschi (2003), working on similar sites of different watersheds, found a similarity of $61 \%$.

These works are consistent with the River Continuum Concept, i.e. the more structurally similar the environments, the more similar in terms of biological communities they are. Nevertheless, they can't be totally equal, as showed by Minshall et al. (1985), due to features such as climate, geology, presence of tributaries, local lithology, geomorphology and man-made impacts.

With that in mind, we would expect a similarity between 50 and $60 \%$ in our study since the pools are in the same watershed, have no severe antropomorphic impacts and do not have significant structural differences.

We assume that one of the reasons why the similarity does not show the expected value is the influence of the waterfall on the stream communities. This hypothesis is grounded also on the results for biological community dynamics observed in our study.

The effect of the waterfall on fish community is strong as shown by its absence in the upstream pool. The effect of waterfalls in the fish dispersal has already been documented (Súarez et al., 2007; Vilella et al., 2004). We assumed that this occurs because fish have no other way to disperse than to actually swim upstream, being incapable of overcoming great waterfalls.

The effect on tadpoles is directly related to its competitive relationship with fish (Hecnar and M'Closkey, 1997) since amphibians' dispersal is not restricted to the aquatic environment. Thus, the absence of fish above the waterfall makes this pool an appropriate place for the development of tadpoles.

The crustacean community behaved in a similar way to fish. Due to our sampling design, our conclusions for this group are restricted to small decapoda, cladocera and copepoda populations. These groups were present only in the downstream pool and all stages of their life cycle develop in the water, what prevents them to overcome the waterfall barrier and disperse to the upstream environment.

The last result supporting our hypothesis is the presence of the same aquatic insects groups on both pools. In fact, the only exception being Plecoptera, found just in the upstream site. Vieira (2006) found similar results working with better taxonomical resolution on riffles and shallow pools above and below the Morato Fall, what corroborates our assumptions.

This result was already expected mainly due to active dispersal of aquatic insects, which results predominantly from flight in adult life. Bilton et al. (2001) pointed out that this kind of dispersal shows varying degrees according to taxonomic group, situation, and prevailing environmental conditions. This means that the waterfall does not represent a barrier to the dispersal of aquatic insects, these organisms being the mainly responsible for richness maintenance in the upstream pool.

The absence of significant differences in richness means that the energy flux is still continuous throughout the study sites, which agrees with the Vannote's Continuum Concept. On the other hand, the low similarity between the sites clearly indicates a discontinuity on the biological compartment. The different results assessed on richness and similarity data indicate that the barrier does not subject the environment to a discontinuity in dealing with energy but the inefficiency of some organisms to reach the upstream point of the waterfall prevents them from using it.

\section{Acknowledgements}

We like to thank the $\mathrm{O}$ Boticario Foundation (FBPN) for sponsoring this work; as well as Antônio Carlos Cubas (In Memorian) for translating and Luis Claudio Fernandes, Pedro Oswaldo Cruz Stillner and Janaina Medeiros for proofreading this work's manuscript.

\section{References}

BALDAN, LT. 2006. Composição e diversidade da taxocenose de macroinvertebrados bentônicos e sua utilização na avaliaçâo da qualidade de água no Rio do Pinto, Morretes, Paraná, Brasil. Curitiba: Universidade Federal do Paraná. 83 p. [Dissertação de Mestrado em Ecologia e Conservação].

BARRETO, AP. and ARANHA, JMR. 2005. Assembléia de peixes de um riacho da Floresta Atlântica: composição e distribuição espacial (Guaraqueçaba, Paraná, Brasil). Acta Scientiarum, vol. 27, p. 153-160.

BIGARELLA, JJ., BECKER, RD., MATOS, DJ. and WERNER, A. 1978. A Serra do Mar e a porção oriental do Estado do Paraná. Curitiba: Secretaria de Estado do Planejamento, Governo do Paraná. 248 p.

BILTON, DT., FREELAND, JR. and OKAMURA, B. 2001. Dispersal in freshwater invertebrates. Annual Review of Ecology and Systematics, vol. 32, p. 159-181. doi:10.1146/annurev.ecolsys.32.081501.114016

COSTA, SS. and MELO, AS. 2008. Beta diversity in stream macroinvertebrate assemblages: among-site and among-microhabitat components. Hydrobiologia, vol. 598, p. 131-138. 
GILLIAM, JF., FRASER, DF. and ALKINS-KOO, M. 1993. Structures of a tropical stream fish community: a role for biotic interactions. Ecology, vol. 74, p. 18561870. doi:10.2307/1939943

GREATHOUSE, EA. and PRINGLE, CM. 2006. Does the river continuum concept apply on a tropical island? Longitudinal variation in a Puerto Rican stream. Canadian Journal of Fisheries and Aquatic Sciences, vol. 63, p. 134-152. doi:10.1139/f05-201

HAMMER, Ø., HARPER, DAT. and RYAN, PD. 2001. Past: Paleontological Statistics Software Package for Education and Data Analysis. Palaeontologia Electronica, vol. 4, p. 9.

HAUER, FR. and RESH, VH. 1996. Benthic Macroinvertebrates. In: HAUER, FR and AMBERTI, GA. Methods in Stream Ecology. San Diego: Ed. Academic Press. p. 339-370.

HECNAR, SJ. and M'CLOSKEY, RT. 1997. The Effects of predatory fish on amphibian species richness and distribution. Biological Conservation, vol. 79, p. 123131. doi:10.1016/S0006-3207(96)00113-9

HELTSHE, J. and FORRESTER, NE. 1983. Estimating species richness using the jackknife procedure. Biometrics, vol. 39, p. 1-11. PMid:6871338. doi: $10.2307 / 2530802$

MAZZONI, R., FENERICH-VERANI, N, CARAMASCHI, EP. and IGLESIAS-RIOS, R. 2006. Stream-Dwelling Fish Communities from an Atlantic Rainforest Drainage. Brazilian Archives of Biology and Technology, vol. 49, p. 249-256. doi:10.1590/ S1516-89132006000300010

MELO, AS. 2003. Diversidade de Macroinvertebrados em Riachos. In: CULLEN JUNIOR, L., RUDRAN, R. and VALLADARES-PÁDUA, C. Métodos de Estudos em Biologia da Conservação e Manejo da Vida Silvestre. Curitiba: Editora UFPR. p. 69-90. doi:10.2307/1468184

MELO, AS. and FROELICH, CG. 2001. Macroinvertebrates in neotropical streams: richness patterns along a catchment and assemblage structure between 2 seasons. Journal of North American Benthological Society, vol. 20, p. 1-16.

MERRIT, RW., RESH, VH. and CUMMINS, KW. 1996. Design of Aquatic Insects Studies: Collecting, Sampling and Rearing Procedures. In: MERRIT, RW. and CUMMINS, KW. An introduction to the aquatic insects of North America. Dubuque: Kendall/ Hunt. p. 12-28.

MINSHALL, GW., CUMMINS, KW., PETERSEN, RC., CUSHING, CE., BRUNS, DA., SEDELL, JR. and VANNOTE, RL. 1985. Developments in stream ecosystem theory. Canadian Journal of Fisheries and Aquatic Sciences, vol. 42, p. 1045-1055. doi:10.1139/ f85-130

MOTTA, RL. and UIEDA, VS. 2005. Food web structure in a tropical stream ecosystem. Austral Ecology, vol. 30, p. 58-73. doi:10.1111/j.14429993.2005.01424.x
MYERS, N., MITTERMEIER, RA., MITTERMEIER, CG., FONSECA, GAB. and KENT, J. 2000. Biodiversity hotspots for conservation priorities. Nature, vol. 403, p. 853-858. PMid:10706275. doi: $10.1038 / 35002501$

PAVANELLI, CS. and CARAMASCHI, EP. 2003. Temporal and spatial distribution of the Ichthyofauna in two streams of the upper Rio Parana basin. Brazilian Archives of Biology and Technology, vol. 46, p. 271-280. doi:10.1590/S1516-89132003000200019

PÉREZ, GR. 1988. Guía para el Estudio de los Macroinvertebrados Acuáticos del Departamento de Antioquia. Bogotá: Editorial Presencia Ltda.

POR, FD. 1992. Sooretama: the atlantic Rainforest of Brasil. The Hague, The Netherlands: SPB Academic Publishing.

REZNICK, DN. and GHALAMBOR, CK. 2005. Selection in nature: experimental manipulations of natural populations. Integrative and Comparative Biology, vol. 45, p. 456-462. doi:10.1093/ icb/45.3.456

ROQUE, FO., TRIVINHO-STRIXINO, S., STRIXINO, G., AGOSTINHO, RC. and FOGO, JC. 2003. Benthic macroinvertebrates in streams of the Jaragua State Park (Southeast of Brazil) considering multiple spatial scales. Journal of Insect Conservation, vol. 7, p. 63-72. doi:10.1023/A:1025505323668

SCHMID-ARAYA, JM., SCHMID, PE., ROBERTSON, A., WINTERBOTTOM, J., GJERLOV, C. and HILDREW, AG. 2002. Connectance in stream food webs. Journal of Animal Ecology, vol. 71, p. 1056-1062. doi:10.1046/j.1365-2656.2002.00668.x

SÚAREZ, YR., VALÉRIO, SB., TONDADO, KK., FLORENTINO, AC., FELIPE, TRA., XIMENES, LQL. and LOURENÇO, LS. 2007. Fish Species Diversity in Headwaters Streams of Paraguay and Paraná Basins. Brazilian Archives of Biology and Technology, vol. 50, p. 1033-1042.

VANNOTE, RL., MINSHALL, GW., CUMMINGS, KW., SEDELL, JR. and CUSHING, CE. 1980. The River Continuum Concept. Canadian Journal of Fisheries and Aquatic Sciences, vol. 37, p. 130-137. doi:10.1139/f80-017

VIEIRA, MEM. 2006. A comunidade de macroinvertebrados em dois trechos do Rio Morato (Guaraqueçaba, PR): estrutura, composição e ocupação espacial. Curitiba: Universidade Federal do Paraná. 48 p. [Dissertação de Mestrado em Ecologia e Conservação].

VILELLA, FS., BECKER, FG., HARTZ, SM. and BARBIERI, G. 2004. Relation between environmental variables and aquatic megafauna in a first order stream of the Atlantic Forest, southern Brazil. Hydrobiologia, vol. 528, p. 17-30. doi:10.1007/s10750-004-0688-6.

Received: 17 November 2010 Accepted: 24 April 2011 